\title{
Bauxite Mining Conflicts in Guinea: Causes Identification, Analysis, and Countermeasures
}

\author{
Issiagha Camara ${ }^{1,}$, , Jiang Deyi ${ }^{1}$, Oumar Barry ${ }^{2}$, Frederick Caille ${ }^{2}$ \\ ${ }^{1}$ School of Resources and Safety Engineering, Chongqing University, Chongqing, China \\ ${ }^{2}$ Department of Political Science, University of Lyon, Lyon, France \\ Email address: \\ issiaghaismgb@gmail.com (I. Camara),deyij@cqu.edu.cn (Jiang Deyi), oumartotyabarry@gmail.com (O. Barry), \\ fredcaille@hotmail.com (F. Caille) \\ ${ }^{*}$ Corresponding author
}

\section{To cite this article:}

Issiagha Camara, Jiang Deyi, Oumar Barry, Frederick Caille. Bauxite Mining Conflicts in Guinea: Causes Identification, Analysis, and Countermeasures. International Journal of Mineral Processing and Extractive Metallurgy. Vol. 6, No. 3, 2021, pp. 53-66. doi: 10.11648/j.ijmpem.20210603.13

Received: August 5, 2021; Accepted: August 17, 2021; Published: August 27, 2021

\begin{abstract}
Mining conflicts are among the most widespread issues linked to natural resources development and management in mineral-rich countries. Guinea mining industries development presents a huge challenge in promoting integrated, prosperous, peaceful, and sustainable mining. The scramble of companies to exploit bauxite in the Boké region is correlated with a wave of protests and violent conflicts. This article explores the reasons for the resurgence of conflicts in the Guinea Republic, proposes some strategies for better mining conflicts prevention, management in Boke region. Thus, through a survey carried out in 7 Municipalities of the region and other mining localities of the country, we use a quantitative approach through descriptive statistic elements to identify the causes of the outburst of the conflict in Boke which seriously hinders the climate of socioeconomic activities for local development. The outcomes of this study reveal that youth employment, water and electricity supply, the weakness in the management of compensation mechanism are the main reasons for conflict escalation in Boke. Although, solutions proposed by the state and some NGOs appear to be hopeful. However, better management of public services and good governance based on more innovative public-private partnerships, and changes in government policy to better benefit the local communities could solve these problems holistically. The implementation of a better strategy (approach) in the management of relations with the surrounding communities by considering the depths and the sociohistorical, cultural, economic characteristics of the region would guarantee an environment of peaceful cohabitation between the local communities and the companies.
\end{abstract}

Keywords: Boké, Conflict Indicators, Fria Syndrome, Local Economic Development Fund, National Agency for Collectivity Financing, Employment

\section{Introduction}

The harmonious development of a nation is directly related to the development of its endowed natural resources, renewable or not. The extractive industry such as mining is among the most dynamic natural resource development activities which have been experiencing a worldwide boom and its management has been needed of a more comprehensive approach, as the industry is facing manifold demands from various actors [1], and the outburst, resurgence or escalation of conflicts often linked to these resources mismanagement [1-3].

Nevertheless, mineral resource developments also induce many environmental, political, and social problems that can only be prevented through cooperation and commitment to sustainable practices [1, 4-7]. Most researchers also have argued that the main upstream of these mining conflicts between communities and companies on contextual and local scale lie in various aspects, ranging from the governance policy of mining resources related to the mining policy and income distribution [6,8-11]; environmental damage of mining activities to communities such as disruption of cultivable land and water pollution, deforestation, etc., considered for a long time as conflict triggering events between foreign companies and local communities [12-15]; and the social framework which concerns the failure to 
respect the local content, the corporate social responsibility (CSR) towards local communities, and concerns about the scarcity of traditional means of subsistence [16-18].

Based on the ongoing increase in the threatening and concerns about the discordant voices that speak out against the environmental impacts associated with the oil industries in the Middle East [19], in the USA [20], in Russia, or China; the protests that are also erected against gold mining projects in Peru [21], Ghana, and Kazakhstan [2, 22]; of Copper mining in Papua New Guinea, or violent protests against bauxite mining industries in Guinea which have often caused serious impacts to companies, communities and the governments around the world.

Though, according to SMB Community Relation Service in Guinea, from 2015 to 2018, the Boké prefecture recorded 35 movements of revolts and road barricades (blocks) by the communities against the mining operations of the SMB. This had resulted in the loss of human life, destruction of heavy machinery of mining companies, as well as administrative buildings of the State.

Faced with these multi-conflicting events which, therefore, can seriously hamper the opportunities for the transformation by the State and companies of the "geological scandal" in the Boké region into a real "economic miracle"; and generate violence on local communities, what underlies these resurgences of conflicts? What new challenges (countermeasures) can the government consider for a peaceful environment for sustainable mining activities that are beneficial to all?

Surprisingly, trying to find answers to these questions of global interest for Guineans, this study reveals (presents) new conflict drivers and triggering events that are mainly rooted in the lack of electricity and water, youth unemployment, mismanagement of compensation mechanisms, and the Local Economic Development Fund (FODEL). These appear as a novelty in the previous literature of its kinds, and specifically in the case of bauxite mining in Guinea; although the key conflict determinants appear almost the same. According to the research outcome held in the target study areas, supported by previous kinds of literature, we have also classified the mining conflicts into 7categories based on conflicts determinants and indicators which characterize them, and the socio-historical, economic, political, and cultural peculiarities of the region. This makes it possible to better manage the various factors (determinants) of the conflicts at their sources, and to prevent potential conflicts in the various localities. In case of conflict, to find an easier and more effective factual management and solution.

However, Guinea's development can be tightened to the mining of its mineral resources. Yet, the conflictive events which have been unbalancing the ongoing economic growth of the country may hinder its development process. Finally, between these two contrasts, there is a more symmetric approach that can contribute towards a peaceful mining industry development, community, and country's economic increase. For this new approach, the economic progress can pass through the exploitation of mineral resources when both are founded on a suitable governance mechanism in a good political context which may help to contain conflicts, monitor, and manage them positively.

In this paper, we present only the results of the case study concerning some localities in the Boké region. Regardless of the specific location of mining activities in that region, some commonships to impacts (conflicts' reasons) are certainly visible (evident) in other mining locations across the country (Fria, Siguiri, Dinguiraye). Hence, through the case study of Boké prefecture, it is possible to suppose the dynamics and characteristics of the socio-economic impacts of mining in Guinea, to propose solutions regarding the management and address of mining conflicts in the whole country.

Nevertheless, the significance of this study appears in the identification of new scientific approaches that can contribute as an instrument for better mineral resources' conflicts prevention and management by decision-makers and companie through a responsible mining practices; a fair, efficient management of those resources development and its benefits for all the population and stakeholders. This can permit the government to establish a favorable environment for foreign investment in bauxite areas, thus creating opportunities such as jobs for communities, contributing to the development of other economic sectors. This paper can also be used by students and researchers as a guide for scientific purposes related to its kind of research. No research has dealt with the specific case of mining conflicts in Guinea and particularly conflicts associated with the exploitation of bauxite ores in the Boke region, which is the so-called bauxite geological scandal and the first Special Economic Zone of the country. On the other hand, some authors such as Penda (2014) have dealt with issues surrounding artisanal and small-scale diamond mining [23]; and Bolay (2017) have also worked on artisanal gold mining industries in Upper Guinea [24, 25]. These mineral resources are also widespread and associated with bauxite mining, contribute over $85 \%$ to Guinea national foreign exchange [26].

\section{Literature Review}

Natural resource development such as mining industries is one of the most rational ways implemented in many resource-rich countries to strengthen economic growth locally, regionally, and pursue national development [14].

Instead of lightening the national economy and support development, as supposed, mineral resources have been considered playing a dynamic role in natural resource conflicts by financing or supporting fighting groups in civil war, For example, the diamond was the source of funding the RUF (Revolutionary United Front) and UNITA $^{1}$ (União Nacional para the Independência Total de Angola in Portuguese) rebel groups against their governments respectively in Sierra Leone and Angola [27]; gold mining in Democratic Republic of Congo (DRC) experienced violent conflicts with the rebel group in Ituri district [24, 28]; In Darfur, for territorial control Because of oil caused about 800 people killed in 2013 [27, 29], all these represent evidence of the linkup to the concerning so-called "resource curse"

1 National Union for the Total Independence of Angola 
syndrome, which has obtained increasing, in recent years, and spreading over in many ways in different countries. The wealth of natural resources is seen as a dichotomous situation between blessing and impasse for local socio-economic development in most mining countries.

Many authors have argued through shreds of evidence that many countries with abundant natural resources are more likely to have less economic performance (growth) or income range than those with less natural resources [30-32]. This paradox between the mineral wealth of some countries and the poverty of the vast majority of their populations serves as an explanatory basis for this famous "curse" on a local scale (contextual, regional, and local level). Dependence on some sources of income generally hampers the diversification of the economy, increases price volatility and revenues, and leads to overheating of the economy $[32,33]$. A Great endowment in natural resources can also often lead to government mismanagement and corruption [34]. Therefore, this contrast between natural potential endowment, the economic situation, and the poverty level in mining area appears as the most obvious reason for conflicts escalation between companies, the state, and communities in most mining countries because of the poverty and the social frustrations that it generates [30, 35].

Moreover, several other studies have also attempted to understand the dynamics that exist between conflicts over natural resources and the various causes of these conflicts, ranging from simple protests to civil wars. Though, to better surround the correlation between natural resources and conflicts' sources, O'Brochta (2019) suggested that, future researchers should be more focused on studying the factors instead of continuing to seek for establishing aggregate relations [30]. That is one of the points in the purposes of this research which are focus essentially on the identification of causes, determinants of the outburst of mining conflicts, and countermeasures (prevention, management strategies) of these conflicts on bauxite mining area in Boke, Republic of Guinea.

Andrew et all (2017), who have also searched on the role of host country governments in instigating or resolving mining disputes between companies and the community in some African countries asserted that an establishment of mining industries for responsible and sustainable mining practices require in the state a mining governance system which aims a rational sharing of the benefits to the local communities and the population as well while reducing environmental and social effects. Moreover, the state could only play the prevention and management role on conflicts based on the socio-environmental factor, when it establishes and maintains an appropriate contextual environment for mining operations [18].

\section{Bauxite Mining Boom in Boke and Conflicts Associated}

Guinea is a country in West Africa [36] with huge useful mineral deposits, such as bauxite, iron, gold, and diamonds, which represent the essential minerals for the national economy. But it is bauxite deposits that must be given the credit for the mining sector based-economic development. This is because around $80 \%$ of the foreign exchange of Guinea results from the joint venture bauxite mining industries in Northwest Guinea, in the region of the so-called bowés $^{2}$, in Boke region [37]. Bauxite is the main ore of aluminum which, through metallurgical processes, is smelted from alumina extracted from raw bauxite $[19,38]$. Over the past decade, Boké has become the preeminent global focus area for large mining companies seeking the host rock for the main aluminum metal which is needed in the automotive, aviation, shutter, aeronautics, pharmaceutical industries, etc.

The last few years have been marked by the promotion and dynamism of the bauxite and alumina sector to make it more efficient, profitable, and more competitive, with a drastic increase in mining production. More than 10 companies are now mining bauxite, mostly in the Boké region, which operates several opencast mines. Thus, since the amendment and adoption of the new 2010 mining code in 2013, the number and production of bauxite mining companies has steadily increased over the years; ranging from a total of 16million tonnes in 2013 to 42 million in 2018 against 15.7 million in 2009; and the planning production for 2020 was 66.2 million tones which finally reached 70 millions tones [26, 37]. This justifies the great outburst (boom) of mining activities in the Boké region as presented in figure 1.
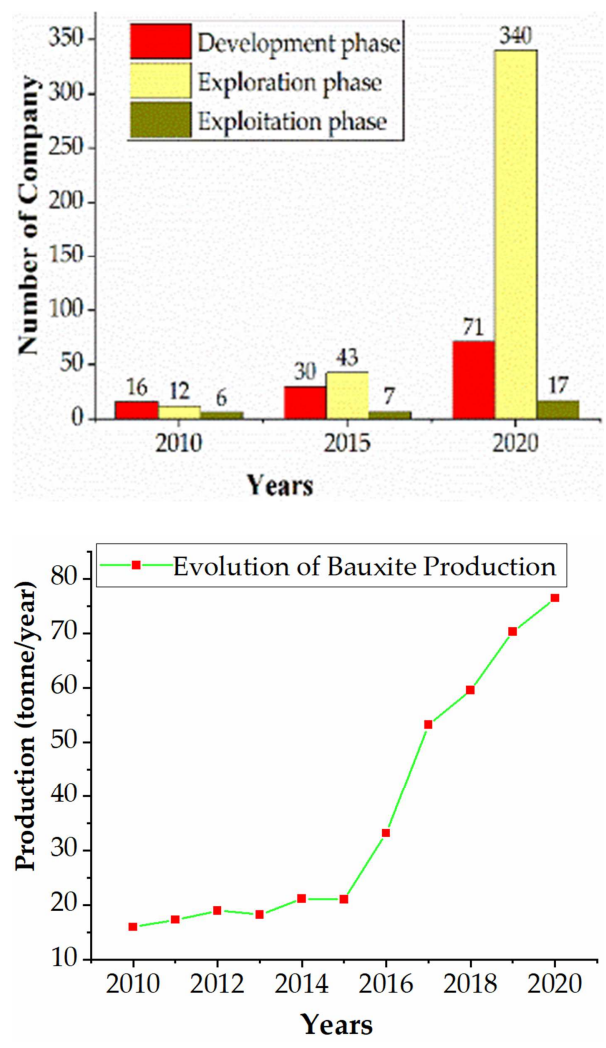

Figure 1. Guinea Mining activities evolution; Source: Ministry of Mines and Geology.

Moreover, eight (8) mining ports ensuring the daily

2 Bowés means plateaus in Guinea Fulani local language 
transport of these extracted bauxite ores are constructed in Dapilon, Katougouma, Taressa, and Kamsar by SMB (Société Miniere de Boke), Rusal Company, GAC (Guinea Alumina Corporation), CBG (Compagnie des Bauxites de Guinee), and Ashapura port are under construction. The rate of transshipment of bauxite ore is appalling. Therefore, more than 23 barges of 8,000 tons each pulled by 28 towing boats invest the river daily for the only port of Katougouma, towards the high seas where large ore carriers, Cape Sizes of 210,000 tons await. As its consequences, pollution of the river, destruction of artisanal fishing nets, spillage of oil in the river, destruction of the mangrove, the exodus of fishermen, the disappearance of aquatic fauna, destruction of an endogenous economy dominated by primary activities (agriculture, animal husbandry), erasure of historical and cultural heritage have been all the damages caused in this battle for port infrastructures [37]. In addition, the bauxite mining boom in the region is also the matter of hyperpolluting extraction techniques connected with surface mining such as blasting, processing sludge mud, untreated wastewater, and tailing storage [38].

Until 2010, CBG only mined bauxite in Boké, Sangaredi. And now, more than a dozen companies have been operating in surface mines since the adoption of the new mining code in 2013 [26]. However, the effect inventory table (list) is admittedly actually too bleak. But the revenues continue to feed the state budget. Bauxite provided $63.58 \%$ of all state mining revenues, more than GNF 300million in 2018 [26]. While the poverty level of communities remains almost stagnant with more than $30 \%$ of the population living under the poverty line [39]. The contrast is, however, evident. Boke region can become the main strategic area for socioeconomic development of the country based on the mining industry because it possesses about $57 \%$ of the national bauxite reserve, which accounts for more than $26 \%$ of the GDP and $60 \%$ of state budget revenue [26, 37]. This is the reason why it is selected as the Special Economic Zone (SEZ) following an official decree from the President of the Republic. SEZ is a "free zone" enjoying tax and customs exemptions and some economic advantages [40]. The objective of the SEZ is to attract foreign investment in disadvantaged regions or to stimulate the development of areas with strong agricultural or mining potential. On the other hand, the dispersion of mining infrastructures over mining localities loaded with historical challenges, ecological issues, and vital interests for the populations with an ineffective mechanism of compensation and unfair benefit distribution, compromise the capacities of communities to survive post-mining, hamper the exploitation of non-mining potential such as agriculture especially [41, 42], since $40 \%$ of BOKE's surface area is provided with fertile soils $[6,43]$. These realities originated in 2019 with more than a hundred conflicts in the region of Boke. This paradox seems to depend on a simple political will to establish and implement a well-integrated governance mechanism on these enormous natural resources.

\section{Materials and Methods}

In the aim of finding the possibility of peaceful cohabitation between the communities and mining companies in Boké prefecture, we conducted a study on the outburst of mining conflicts in the Boké region, the Republic of Guinea to firstly identify the cause of the conflicts; and then, propose some strategies to prevent, manage or address them. However, data and outcomes of our research are the fruit of surveys, which are conducted through interviews carried out in the mining areas of the region affected by conflictive events (Boké, Kolaboui, Kamsar, Sangaredi, Malapouya, Kanfarandé, Tanéné, Siguiri, Dinguiraye) operated by many international mining companies, on which we gathered data on the processes surrounding mining conflicts within those locations. Some data were collected from NGOs and the local press who provided us several information and documents related to our research theme (topic). The interviews were held in the Boke region from July to the end of September $2019^{3}$ with the assistance of some local partners.

The data collected includes 35 semi-structured thematic interviews of which the 15 interviews with the public administration representatives, 6 local authorities, 8 representatives of a civil society composed of youth association leaders, NGOs, civil society leaders, youth leaders, media members, and some local community members. An interview was also conducted in the capital city of Conakry, with a state environmental expert while the remaining interviews were made in Boké at the mining sites.

For the data collection, we proceeded by the common techniques of snowball sampling, which is more appropriate to touch groups difficult to reach for some specific reasons. We also collected some data from the digital platform, the KobotoolBox server, designed for the implementation of the Early Warning Respond System (EWRS) by the National Agency for Collectivity Financing (ANAFIC) with World Bank support in Boke region.

Their research approach was based on the qualitative type (socio-anthropological, which consider the values, customs, and representations of the public surveyed), combined with the quantitative method through survey and data processing tools (computerized and printed) beforehand designed and oriented towards the targeted areas of investigation; Focus group interview guides (or discussion group) for the collection of qualitative data and the digital server-based platform KobotoolBox designed, put online for instant data entry and transfer, through the combined use of kobocollect and the statistical software "SPSS" for data processing and analysis, constitute the key tools used for the survey. "Android tablets and phones" served as a survey medium for the "Kobocollect digital questionnaire" because it is more appropriate with new communication technologies. The chosen sampling mode is reasoned random sampling.

3After the field study, the Covid-19 outbreak stopped the data collection in the mining locations, and because of the ripost strategies any conflict has been noted until. 
In addition, we used the results of a survey of 200 respondents at the Boké's Youth Forum in Kamsar held from 10 to 12 September 2019. Hence, 10 focus groups were held with 20 respondents in each group. The interviews include both groups and individuals from each of all the concerning mining areas. The participants in the focus groups are chosen to meet the criteria of social representativeness in Guinea. These criteria are based primarily on availability, age, and gender. Some interviews were conducted at mining sites with mine workers. That provided the best way to reach all the target groups and an opportunity to make observations in working areas, environment, and on the living conditions of the local communities proper.

Then, the route method or Politz method used for the surveys carried out by WANEP will serve as a basis for drawing samples in the 7 target municipalities according to the criteria of potentiality and/or conflictual recurrence. The conflict sensitivity approach is used to manage the sensitivity of the investigated public based on ethical consideration of informed consent. Quality assurance is based on triangulation; prior training of interviewers and testing of tools, supervision of the field survey (Consultant and SPV ${ }^{4}$ team), and the GPS tracking mode incorporated into the digitalized survey system by the survey was applied.

\section{Results and Discussion}

The analysis of data collected with respondents in the target areas is an essential element in identifying the causes of conflict, as well as in understanding the attitudes, practices, and efforts of stakeholders for the peaceful cohabitation of actors to promote sustainable practices of economic activities in general, and mining in particular. However, in Guinea, the criteria for social representativeness are essentially based on availability, age, and sex. In considering the gender, the results of the survey presented $85 \%$ of respondents among men and $15 \%$ of women. The distribution of respondents by age group generally indicated more than $55 \%$ of the respondents are between 36-54 years old. In addition, according to the survey outcomes of ANAFIG, about $95 \%$ of respondents know the concept of conflict. They understand the notion of conflict as related to the lack of employment for autochthonal youth, low fulfillment with basic social needs (water, electricity, etc.), political violence against party activists, disputes between indigenous peoples and residents, clashes between farmers and herders, family problems related to inheritance, environmental pollution and destruction of rice-growing and/or agricultural land, and failure to respect the commitments made in the resolution of previous conflicts between protesters and stakeholders [44]. However, the cartography of conflicts in Guinea draws some common typologies of conflicts; it turned out that conflictive crises fall within the economic, socio-political, and socio-cultural fields. This makes it possible to define that the causes of these various conflicts are to be found in the political,

4 SPVC: Support Program for Village Communities. economic, and socio-cultural situation of the country. Hence, this made it possible to retain from the outcome of the survey the main sectors on which conflicts are likely to be related in the study area of Boke; as follow, we can mention:

1. The economic sector (mining conflicts, land and ownership conflicts, conflicts between farmers-herders, etc.);

2. The political sector (political conflicts);

3. The cultural sector (inter-religious conflicts, social class conflicts, etc.);

4. The external area;

These are illustrated in the figure 2 below.

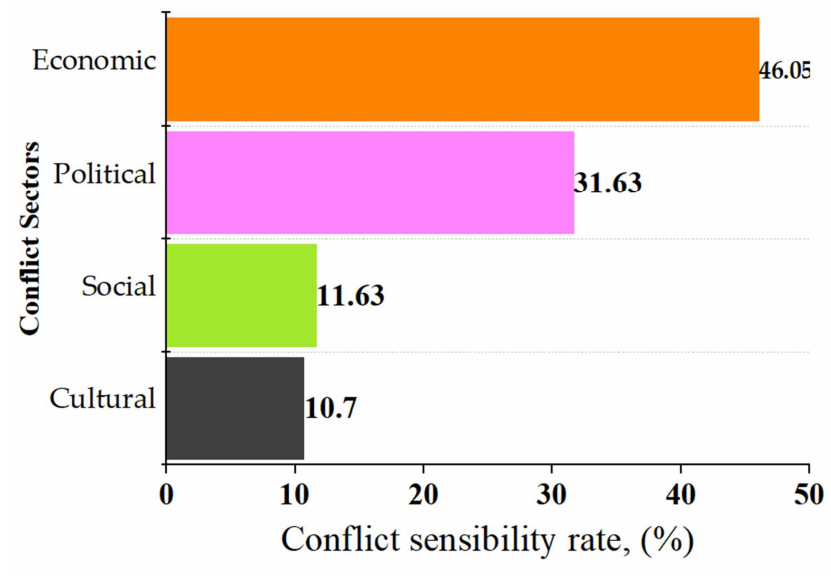

Figure 2. Conflict Sectors sensibility rate.

Beyond this classification of conflicts based on the activity sectors, Figure 2 obtained from the outcome of the surveys provided a more detailed illustration of the degree of conflict for the previous sectors, namely in Table 1 .

Table 1. Conflict Sector Number and linkage activities.

\begin{tabular}{|c|c|c|c|}
\hline $\begin{array}{l}\text { Conflict } \\
\text { Sector }\end{array}$ & Linkage & $\begin{array}{l}\text { Number of } \\
\text { conflicts }\end{array}$ & $\begin{array}{l}\text { Frequency } \\
\%\end{array}$ \\
\hline Economic & $\begin{array}{l}\text { Mining activities, farmers and } \\
\text { herders, basic social services. }\end{array}$ & 60 & 45.4 \\
\hline Political & Political party activists & 43 & 32.6 \\
\hline Cultural & $\begin{array}{l}\text { Social classes and religious } \\
\text { conflicts }\end{array}$ & 15 & 11.4 \\
\hline Social & $\begin{array}{l}\text { socio-community, social } \\
\text { activities, families }\end{array}$ & 14 & 10.6 \\
\hline Total & & 132 & 100 \\
\hline
\end{tabular}

The conflicts for the economic sector, are linked to conflicts based on mining activities, conflicts between farmers and herders, conflicts related to access to basic social services (water, electricity), and accounted for $45.4 \%$ of the conflicts in Boke; $32.6 \%$ of the conflicts represented political conflicts, which are caused by clashes between political party activists; $11.4 \%$ of cultural conflicts included conflicts between social classes and religious conflicts; $10.6 \%$ of socio-community conflicts, and others kind of community conflicts.

Through the results of the in-depth investigation based on conflict indicators, we found that $30 \%$ of conflicts are linked to mining activities (A), 26\% are related to land conflicts (B), 
$19 \%$ to farmers and herders (C), 12\% are linked to sociopolitical conflicts (D) and $10 \%$ to inter-communal conflicts (E), $2 \%$ to inter-religious conflicts (F), $1 \%$ to conflicts between social classes $(\mathrm{G})$ and $0,3 \%$ to conflicts related to access to basic services $(\mathrm{H})$. "Figure 3" represents the distribution of these conflict indicators as cited.

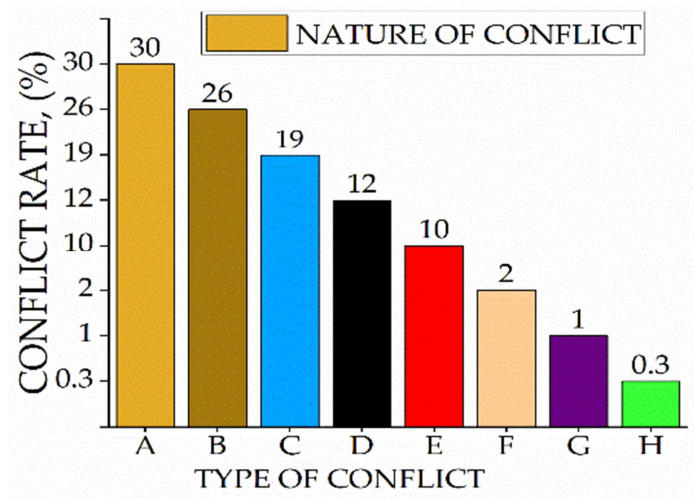

Figure 3. Type of Conflict.

Beyond these mentioned causes of clashes, protests, or conflicts in the Boké zone, certain impacts of bauxite mining raised by other investigations report in the zone (in particular by Human Rights Watch), may in the medium term made up of the real causes of conflicts: The scarcity of water resources due to the disruption (deterioration) of the water quality of rivers, streams, and wells on which the populations depend on; especially in the villages around the mining activity sites of the SMB; health threats aggravated by dust produced from the extraction and haulage of bauxite [44], etc.

\subsection{For Bauxite Mining, Boxing Sites: To Whom Is the Fault}

Mining companies still used methods that had huge damage on the environment and livelihoods such as " "blasting", that cracks homes in villages sometimes located a few meters from the mine [45], have been used by SMB (Boke Mining Company) in Katougouma Malapouya and Dabiss mine [38]; the inappropriate disposal of bauxite residues, the spilling of certain toxic wastes directly into some rivers in Sangaredi [38], and the increasing of open pits have become the source of environmental damage (degradation) [46] in Boke region, which pose numerous dangers for the community. Sidiki (2019) states that deep blast holes used by $\mathrm{CBG}$, associated with the poor management of residues of bauxite polluting rivers [47] have also been seriously affecting Sangaredi rivers and water table $[38,47]$. All these factors kicked in the frustration and sometimes protest of the populations in Boke region $[19,48]$. However, based on the outcomes of the survey, the environment is not seen by the respondent as a direct conflict trigger, but It lies beneath the latent conflicts which are often accompanied by other conflict-triggering events for its outburst (escalation or resurgence). Moreover, the environment in the region is threatened by huge direct and/or indirect impacts on the whole ecosystem. Some are very common and evident in mining areas such as land changes [45, 49], destruction of grasslands [19, 50], rivers and sources pollution [51], destruction of agricultural areas, and the decrease of its productions [46, 52], and so on, negatively affecting the means of subsistence of the populations, causing the scarcity of certain essential resources (water, food) and degrading (decreasing) the quality of life in the whole region. This statement on the tensions surrounding conflicts linked to mining activities has been mentioned by the community leader in Kolaboui and reported by PACV as following:

"We are frustrated that the SMB tells us that we are not impacted and yet we are a few "ghabbun" away from their fields. We don't get anything from them, while our neighbors benefit from a lot of things. Today we are experiencing the effect of dust, they have seized our plains where we used to work, the water of the plain is mixed with Karsin 6 ,"

Finally, the boom in bauxite ores development in the Boké region has set off many violent protests over the environmental degradation as previously mentioned, inequitable distribution of benefits from mining companies in the case of the FODEL's (5\% of conflicts) the management, community relocation, and compensation processes which represent $6 \%$ of conflict-triggering events, and unfair compensation for losses of subsistence income and agricultural land. Moreover, Subsistence farmers have been displaced from their lands, water supplies (springs, streams) have been polluted, companies are settling up in large numbers but the youth unemployment curve continues to climb from $30 \%$ in 2012 to about $35 \%$ in 2020 from the World Bank, the lack of basic social services is also more visible and represent $0.3 \%$ conflict outburst [44], and the protests themselves have sometimes resulted to fatalities because of the abuses of security forces against protesters by shooting with real bullets mentioned some respondents. The Guinea mining sector is constrained by the lack of an appropriately qualified local workforce, the lack of mining infrastructure since the dawn of the country's mining activities. Due to this constraint, mining companies are compelled to hire a large part of their workforce from neighboring countries [53].

However, according to data collected on the "Kobocollect" platform of ANAFIC for its pilot experimental project for the implementation of the EWRS as part of conflict prevention, it is surprising to find that conflicts related to access to basic social services are $0.3 \%$, whereas, in practice, our investigation reveals, over $60 \%$ of the demands of the Boké's protest movements claims to provide basic social services (electricity, water, etc.). According to our analysis, this explains the lack of sincerity in the responses of the target population during the survey or some mistakes in the methodology of the investigation for data collection. There

\footnotetext{
5 Ghabbun: way of expressing shortest distances in Pular, a local language in Guinea, assimulable to a "micron".

6 Karsin is the name of diesel in fulani language in guinea.
} 
was only one person according to their report assumed as a local community leader who was part of the basic investigation team. That is insignificant for locals in data collection for the EWRS in those areas. DR Subedi (2017) suggested that the better identification of potential violence or conflict indicators needs local expertise, actors as well as women, youth, and civil society. It requires a bottom-up and localized approach for the collection and analysis of information for the implementation of the EWRS. That means the survey team needs more community members for the field investigation for the implementation of the EWRS in the localities. In their speeches, respondents tend to place these conflicts to access to basic social services in mining conflicts, although they are aware that the local distribution of these services should be provided by state services. In their understanding, consistency in the provision of these social services depends on financing by mining companies. This justifies the attribution of deficiencies at this level to mining industries (companies) in the area. It explains the fact that the protest movements related to these basic social services are directed to these mining companies. Nevertheless, the very complex issue of employment, which is often put forward in the demands of young people $(60 \%)$, would require a more in-depth study considering the sociohistorical of the Boké region and the structuring of the main economic activities in the region. To reduce the gap of unemployment to some extent, the government can implement an educational system and vocational training reform plan, and adopt a policy to promote small- and medium-sized enterprises, promote investments in highemployability sectors, such as agriculture, can speed up job creation and improve social and economic conditions in the mining localities [53]. However, the people living near the activity areas obtain less employment, business opportunities, and other linked advantages [54]. These facts are an open transgression of the local content in the CSR Program.

In recent years, respondents said that protests and demonstrations have occurred in almost all prefectures in Boke region. But uprisings are very often not aimed to attack mining companies. Youth movements first target the symbols of the state (public buildings, services) for a response to their demands, and then, they barricade the transportation infrastructures (mining roads, railways) of mining companies through the principle of "Cause and Effect"; that is, shutting down the operation of mining companies to draw the state's attention to their problems. Social conflict or protest can be avoided if a consensus is found between current companies and the community in regards to the Corporate Social Responsibility (CSR) programs that should be imparted in CSR Report [1].

\subsection{Identification, Analysis of Mining Conflicts in Boke Region}

Mining Industries are awaited to bring new wealth to communities in their operating area; but it can also result in considerable mar to the locality, government, and company $[15,54]$ New mining projects are synonymous with jobs creation, increase in business activities, roads and new social infrastructures such as health clinics, schools to remote mining areas. Unfortunately, the mining profit used to be unfairly distributed, and for some, they may receive poor compensation for their losses of livelihoods and the disruption of their socio-cultural heritage and environment [55]. This uneven share of benefit [56], the inadequate and undoubted compensation processes of the community rights can easily lead to a social contest which can sometimes end in violent conflict [18].

However, the conflicts in Boké mining areas are very diverse and varied, as in most of the country's mining areas. Among them, there are conflicts between much older and less intense farmer-herders (19\%) in recent years, between community and mining companies, between communities and the state. But the most recurrent conflicts in the past decade concern mining conflicts (30\%). In this article, mining conflict refers to conflict, protestor, revolt, and legal or procedure that hinders mining activities or causes losses, damages to a company in the extractive industries area. Mining conflicts are often defined by conflict indicators that characterize them [19]. According to respondents during our investigations in the mining areas in Boké, we identified the following conflicting indicators:

1. Establishment of a mining company, physical or verbal abuse on the site,

2. Youth unemployment,

3. Failure to respect commitments vis-à-vis the communities,

4. Destruction of cultural sites, water pollution, weakness or lack of basic social services,

5. Accidents on livestock or human beings,

6. Good governance, Management of state public services,

7. Crime, arbitrary dismissal, violation of local content

8. Violation of the principles of compensation

According to Andrew (2017), the conflict pathway analytical framework in which conflict is systematically described within a conflict determinant hierarchy, categorize them from broad-scale (international), and long-term into structural factors and contextual factors (national to regional), conflict drivers (regional to local) and finally conflict triggers which usually occur at the sites of operations [18]. However, in this study, it appears that all the indicators of conflicts are related to the regional scale, local scale, and to mining operation sites (see Table 2); therefore, the determinant of conflicts are among the conflict drivers and conflictstriggering events. The key players in the conflicts are the companies, communities, NGOs, and the government, which is the case in the targeted areas of Boke region. Hence, Through the indicators identified, the conflict factors, and previous kinds of literature, we classified the conflicts into 7 categories (see Table 2 below).

This classification is partly similar to that established by Que et al. (2015) for the classification of factors that influence the acceptability of mining projects in the USA by using discrete choice experiments and modeling [57].

However, the classification of conflicts can be seen as the 
outcome of the unacceptability of mining projects or their practices by communities. The two works are interconnected, because the presence of conflict between communities and mining companies may explain the nature of their cohabitation. But the classification drawn up by our study is based on a non-global socio-cultural qualitative and quantitative approach. That is to say, the sociologic survey was linked to conflictual in a mining area with specific sociocultural values. Comparatively, this study is specific, more detailed, informative to conflict outburst, escalation, or resurgence in mining locality. It is more appropriate to help decision-makers, companies in conflict monitoring and management.

Table 2. List of the factors and types of conflicts that can result.

\begin{tabular}{|c|c|c|}
\hline Conflicts & Indicators & Determinants \\
\hline Intrafamily property & Company establishment, compensation, the extension of the concession & Mines \\
\hline Latent & $\begin{array}{l}\text { Compensation, pollution, arbitrary dismissal, violation of local content, management of compensation } \\
\text { funds, relocation, }\end{array}$ & Mines et environnement \\
\hline Value & Destruction of cultural site & Social culture \\
\hline Autochthony & Establishment, compensation, the extension of the permit, relocation & Societal and Mine \\
\hline Environment & $\begin{array}{l}\text { Pollution, destruction of agricultural or livestock areas, forests, deforestation, degradation of plant } \\
\text { cover }\end{array}$ & Environment \\
\hline Mining & Location, mining operations, environment, local content, accidents & Mines \\
\hline
\end{tabular}

${ }^{1}$ Source: From authors

According to the respondents, In the Boke region, the aggregate problem, at the local level has been the lack of employment and poor interaction, a dialog between companies and local citizens for local development; this hurts the cohabitation atmosphere in the region. Conflicts are generally characterized by a mixed revolt made up largely of young people who represent about $65 \%$ of the population according to the National Institute of Statistics. But all social categories are met among the demonstrators. The old people are secondary actors in the demands.
The method of violence is the modus operandi (mode of operation) of conflicts (breakage, burning of tires on the roadway, destruction of public or private buildings, road blockades, etc). The violent protest in the Boké prefecture takes place exceptionally at night. According to a report by the NGO WANEP, West African Network for Peace-building in Guinea (WANEP-GUINEE), from December 15, 2019, to June 15, 2020, there were 132 addressed conflicts following 399 cases of conflicts in 4 localities in Boké prefecture.

Table 3. Warning and Respond Statistics from December 15, 2019, to June 15, 2020.

\begin{tabular}{llllll}
\hline Prefectures & Locality & Frequency of Conflict Warnings & Addressed conflicts & Frequencies \% & Sensitivity \% \\
\hline \multirow{4}{*}{ BOKE } & Boke city & 75 & 09 & 6.8 & 12.00 \\
& Sangaredi & 148 & 51 & 38.64 & 34.45 \\
TOTAL 1 & Kolaboui & 116 & 48 & 36.36 & 45.28 \\
& Kamsar & 60 & 24 & 18.18 & 40.00 \\
BOFFA & & 399 & 132 & 100 & - \\
& Boffa city & 36 & 07 & 12.28 & 19.44 \\
TOTAL 2 & Douprou & 62 & 28 & 49.12 & 45.16 \\
TOTAL & Mankountan & 50 & 22 & 38.60 & 44.00 \\
\hline
\end{tabular}

Source: NGO WANEP-Guinea/ calculation of conflict and sensitivity rates has been done by authors

The conflict warning (Alert) distributions are presented in Table 3 and Figure 4.

Based on this report, we have identified the number of conflict warnings. "Figure 4" represents the conflict sensitivity according to the studied areas in Boke. Its outcome reveals that the youths in the municipality of Boké are less reactive (has less reaction against) in the face of conflict indicators with a sensitivity rate of $12 \%$ (and $6.8 \%$ of conflicts outburst). The areas of Kamsar and Kolaboui are the most reactive to conflict inhibitors with respectively $40 \%$ and $45.28 \%$ of sensitivity and $18.18 \%$ and $36.36 \%$ of conflicts. The intensification of conflicts in the two (2) localities (Boke and Boffa) can be explained by the contrast between the settlement of mining companies (CBG, the
SMB consortium, ALUFER, China Power Investment, EGA-GAC) and mining infrastructure (mining road, railway, mining port, industrial towns, drying factories, mines pit) and the degradation of the quality of basic social services and the standard of living (water, electricity, health, hygiene, employment). Boffa, a new mining prefecture, is characterized by, very often, passive reactions with few mining conflicts. This can be explained, compared to Boké prefecture, by the misunderstanding of the legal rights of communities vis-à-vis other stakeholders and the consequences of certain impacts caused by mining activities. Moreover, the cohabitation with mining companies is recent in this prefecture (from 2015). 


\subsection{Conflicts Management Strategy in Boke}

\subsubsection{Analysis of Government Perspectives}

Many of the countries are seeking economic growth through the development of their raw-material sectors, but they are also experiencing problems concerning their environment, civil society, and administrative framework $[7,58]$. Therefore, within the framework of the exploitation of bauxite in Guinea, the West African Network for Peace Building (WANEP-GUINEE) is an NGO established in the country in 2013. It is involved in the prevention and management of conflicts (electoral, post-electoral, mining, inter-community, identity conflicts), etc. It has been in Boké since 2019 as part of the implementation of the EWRS funded by the World Bank with the support of ANAFIC which is running a oneyear, scalable 4years pilot project. The project is being tested in 7 communities in Lower Guinea, particularly in the prefecture of Boké and Boffa. For the Boké prefecture, which is our study area, we considered the most conflictual areas, namely Sangarédi, Boké city, Kolaboui, and Kamsar. WANEP has been operating in close collaboration with local elected officials, the community, and decentralized technical services of the state and community leaders as well as the population. WANEP has been worked in the four natural regions of the country with different projects. Mining is well-known to induce multiple environmental, political, and social problems that can be prevented through cooperation and commitment to sustainable practices $[15,59]$.

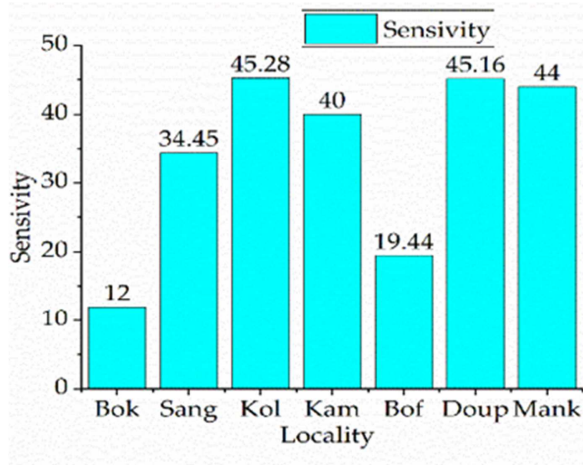

Legend
Bok-Boke
Sang-Sangaredi
Kol-Kolaboui
Kam-Kamsar
Bof-Boffa
Doup-Doupourou
Mank-Mankountan

Figure 4. Diagrams of conflicts in target areas.

These sustainability practices in mining localities are an integral part of communication and dialog between companies and communities to promote peaceful cohabitation $[7,55]$. But, the affected communities and the companies as well have a great challenge to regard their interaction in a good manner. However, the establishment of Community Relations Services (CRS) within mining companies allowed regular communication with local communities (dozens of officers are deployed in all the mining sites daily. Moreover, the technics used for public consultation are generally embryonical, especially for SMB, and are different from one company to another. No specific training for this function is yet offered by academic institutions, specialized cabinets, training centers, or even by mining companies. Officers of CRS developed their own experiences, negotiation, and dialogue skills by routine during conflict resolution processes, and in routine, prolonged contact with communities. These shortcomings observed in the CRS policies of companies have weakened the climate of trust with the communities who, if necessary, opt for (uses) violence for their demands. Therefore, knowledge of the sociohistorical framework of these localities would allow companies to better understand the representations of populations on soil and subsoil resources (sociology of mineral resources), endogenous ecological and environmental cultural codes in conflict with certain industrial practices of mining companies (blasting, destruction of mangroves, pollution of springs and sacred areas).

In the Boké region, the framework of the consultation for conflict management commenced at the grassroots through relay monitors in the neighborhoods and/or districts, then monitors to facilitators and action groups. The action groups are composed of officials from decentralized state technical services, religious leaders, civil society, community leaders, etc. These action groups are represented in the 7 target localities of the project. When conflict is imminent in a locality, the relay monitor feeds the information back to the neighborhood monitor, who in turn informs the facilitator and the latter joins the action group for the management of the indicator, incident, or conflict.

According to the area of claim, the agents in the concerned department should find a rapid solution to the problems. The action group acts as a peacemaker. They also exist at the regional and national levels. The intervention of the action groups depends on the demands of the demonstrators (protesters). If the problems are at the prefectural, regional or national level, the arrangements are made by the action groups of the concerned jurisdiction (prefectural, regional or national). This mechanism of conflict management is called the Early Warning and Response System (EWRS). The significance of early warning lies in the early response outcome. However, the effectiveness of the response mechanism hinges on the quality of early warning information [60].

Most conflicts are often addressed peacefully through meetings with the protagonists of conflicts. Religious leaders and customary chiefs play a significant role in addressing conflict. They have a great influence on local communities. However, traditional conflict resolution always creates a latent conflict situation because most customary or religious authorities are often seen as corrupted by national and local authorities, or mining companies in several localities. Moreover, the mechanism of FODEL management, legal and judicial texts (mining code, labor and land code, environmental code) can be implemented in the framework of conflict management related to mining local areas. This will promote sustainable and reliable stability between communities and mining companies [37]. 


\subsubsection{From the Mining Economy to the Local Sustainable Economy}

Boké is shared between the Baga fishing communities, the farming Landoumas and the pastoral (herder) Fulani. Before the settlement (installation) of the mining companies, the economic life of the region was mainly based on these classic activities for local development (fishing, farming, herding). The World Bank states that the mining activities expansion was supposed to improve the socio-economic situation of the region [7, 39], but according to our investigations, the effects (impact) of mining have not been sole as expected by the local communities.

It should be noted that, said the respondents, mining has more contributed to the impoverishment of the traditional local economy by the rise in the prices of basic consumer products, the high cost of basic social services, even access to primary needs have become expensive and more difficult. Respondents in Boké, for example, informed us that the rent of a single room has increased from $50000 \mathrm{GNF}^{7}$ in 2012 to $250000 \mathrm{GNF} 2020$, the kilo of beef meat has risen from 25000 to $40000 \mathrm{GNF}$, the $50 \mathrm{Kgs}$ of rice bag from 180000 to 300000 GNF.

According to interviews outcomes, this is due to the frequent removal of herds, pollution of rivers and animal watering sources, and the destruction of cultivable land leading to the scarcity of basic consumer products such as rice, corn, vegetables, etc., and the effect of the Covid-19 to the local economy has toughened this situation. These have brought about a rapid increase in the prices of basic foodstuffs and affected the standard of living, the living environment, and the living condition of the populations [42]. This comes down to a direct threat to their communities' overall well-being, which represents the reconciliation of a good standard of living, living environment, and living conditions. However, with the low rate of employment of young people of the locality who, by this state of affairs, find themselves in this situation of extreme precariousness. In this light, a feeling of hatred is developed against mining companies which are assumed to be responsible for their suffering. At the slightest protest, these people become more aggressive and violent.

However, although the mining companies fulfill their obligations to the state, the establishment of a mining company in a locality of the prefecture of Boke is the first indicator of mining conflict. The economic development of the local areas has not been substantial because the industry is not stimulating other sectors in the region as hoped [7]. The economy of Boké prefecture is almost totally dependent on the mining sector. No political reflection is conceived at the local level regarding the post-mine in Boké to avoid the catastrophe of mining dependence and the occurrence of the mining "resource curse" theory $[32,61]$. Therefore, the civil society representative of the municipality affirms that Boké depends about 80 to $90 \%$ on mining revenues. This requires a reorientation of development policy towards the reconversion

7 GNF: It is the local currency of Guinea. of the mining-based economy towards other development sectors such as agriculture, stock raisings, fishing, young entrepreneurship, etc. Moreover, the deconcentration policy of the economic activities implemented around the mining operations areas (mines, processing plant, etc.) can reduce the dependence of communities on the mining industry and downsizes the effect on the depravity of social, cultural, or other changes that may promote the strengthening of power inequity [13]. In addition, the conversion of the local economy to another sector is an appropriate solution for sustainable development, and can also avoid the "Fria syndrome 8 " in Boké. It is in this perspective that the government created FODEL, and has been implementing it in mining prefectures. This fund is the annual tranche of the turnover of companies to finance communities' projects in mining activity localities. The amounts are managed by the structure named Fund Management Support Committee (FMSC) in the communion of ideas and action with the various communities including the urban town. This can allow a new form of redistribution of funds or mining revenues, by financing entrepreneurial projects of young people, groups of men or women, aid for agricultural, livestock, or fishing projects of the communities, etc.

Support to communities, mainly mining areas, by companies based on a public-private partnership with the government for the provision of input services necessary for business operations can become a good means of economic gains for communities and social stability in the localities [62]. However, the establishment of a large scale mining company in a locality can be seen as a booster for growth and changes for better living conditions of residents [18, 63] because of the distribution flow of profits from mining income and the amount for compensation received for damages caused by their operations.

In the past decades, mining companies proceeded by compensation of losses in the environment, social, culture, and livelihood disruption to the directly affected communities by mining operations and its surroundings [64]. However, compensation processes have shown diverse and complex issues. The introduction of monetary compensation for mining communities that previously did not use to practice the cash economy is a real vehicle to transform the traditional economic and social base of communities [55]. Therefore, the ability of the mining company to contribute to the sustainable development of communities mainly depends on the system of the compensation and its management [64]. Because, the experiences have always shown that monetary compensation has had its boundaries and maintained latent conflicts that, in the end, often violence resurged [12, 46, 63].

In Boke region, compensation systems resulted in value contradictions on the space ceded and the amount allocated for compensation. As a result, the lack of management and monitoring of compensation causes major problems between

8 Fria syndrome: Fria is a mining town in Guinea whose life depended almost entirely on the alumina plant installed since 1968. Following a strike, the mine had stopped and the plant closed from April 2012. 
the communities and the operating companies. Individuals received huge amounts of money they have never had before. Over time, the mismanaged amounts end up and cause a kind of hatred among communities by comparing the annual incomes they used to benefit from local economic practices (farms, plantations, livestock, etc.) against the overall amount of compensation. This phenomenon can be resolved with the strategic support of compensated people over time until their entrepreneurial projects are economically stable, matured, and cost-effective. The whole amount should not be given at once to the beneficiary but in line with the ongoing evolution of his entrepreneurial project supervised by a third party (consultant, NGOs, cabinet). Entrepreneurial knowledge based on local economic development activities is a sure and effective means of development of the region independently of mining companies and sustainable support after mining in the area. In addition, regular monitoring and strengthening of technical capacity for accounting and financial management in companies, the development of the entrepreneurial culture of project owners are necessary to sustain the gains already achieved.

In short, it is unfortunate that the huge amounts of money from FODEL intended for the development of mining prefectures have been misappropriated by some responsible for the management of these funds and then continue to keep the communities in extreme precariousness in many mining localities. Is not this also a "Communities Curse" in mining areas face to the development and benefits of their natural resources?

\subsection{Reasons for the Recrudescence of Mining Conflicts}

In conclusion to the research in the mining areas of Boké, we found that the main reasons for the fresh outbursts in mining conflicts can be divided into 2 categories as follow in table 4 .

Table 4. Mining Conflicts outburst triggering Indicator.

\begin{tabular}{lll}
\hline A & Primary Reason & Frequency, \% \\
1 & Weak state to provide basic social services (Water and Electricity) & 60 \\
2 & Youths unemployment & 11 \\
3 & Failure in the principle of compensation, & 5 \\
4 & Poor management of community compensation funds and the FODEL & 6 \\
5 & Non-compliance with a commitment to communities for compensation and relocation & \\
6 & The total dependence of the local economy on the mining activities & \\
$B$ & Secondary Reasons & 2 \\
1 & Poor governance and management of state public services (water and electricity supply) \\
2 & Non-compliance with community development and environmental protection provisions in the mining areas \\
3 & Poor management in the local development entrepreneurial projects & 1 \\
4 & Lack of Environmental and Social Management Plan in mining areas & \\
6 & Unrealistic local expectations towards the mining companies & 0.8 \\
7 & Participation of local authorities and communities in decision-making processes concerning community development projects & 0.5 \\
\hline
\end{tabular}

Overall, it appears that the industry's actors are just starting to acknowledge the importance of managing the social and sociological dimension of mining $[65,66]$. Since locals perceived the government as currently being incapable of providing them with adequate social services and infrastructure, they are targeting their pleas for these services at the mining companies [7].

In the Boké region, the general problem at the local level has been the lack of employment (11\%), poor interaction and dialog between two stakeholders (companies and local communities) for the local development of mining localities; this harms the cohabitation atmosphere in the region. The scarcity of water and the lack of electricity is a common issue for all the country. Therefore, its resolution lies in political wills and changes.

Very often there is also confusion in the complaints of the communities. They do not differentiate their rights face to the companies or the state. This, therefore, could create backlash towards mining companies. When setting up mining companies, civil society does not often take part in the negotiation process of the contract. Qué and all (2015) maintained that the acceptance of a mining project by the communities is conditional on their consultation and their participation as stakeholders in the whole process per their legal rights [57]. However, it is necessary to share the content of mining conventions with representatives of civil society and community representatives at all levels to avoid conflicts before or during mining operations. The communities are only observers in the convention between companies and the state. But they stand up tirelessly for the respect of local content with companies.

The analysis of the mining conflicts case in Boké also reveals that several environmental and social impacts of mining and theirs surrounding issues are linked to the shortcomings in communication between the communities members in the mining localities and the mining companies, as well as actual concerns of communities: livelihoods, irrational expectations of the locals on the mining companies, etc. The reasons for conflict should not be underestimated. Thus, the recrudescence of the conflicts should also be contemplated from the view of the wider Boké societal, sociological and economic situation.

Meanwhile, Boké bauxite extractive industries cannot be publicly (globally) seen as only a negative activity in the mining areas. The growth of the industry has also a positive impact, as on the increase in state budgetary resources, the increase in fund transfers for local development ( $\$ 60$ million for ANAFIC and \$17 million for FODEL in 2019), and local 
activities [26]. New social infrastructures (administrative buildings, health centers, schools) are emerging thanks to funding from ANAFIC (according to the ITIE report, 791 micro-projects were realized in 2019). In addition, Mining compared to agriculture and stock-raising, provides a more reasonable and rather stable income to the population, even in the rainy season when most agricultural activities have ceased. Moreover, the Fishing industry (29000 tonnes from artisanal fishing in 2018) has also a great income result in the economy but mainly on a small scale in its activity areas. Mining companies do contribute to increasing the sales of local agriculture by its workers. Groceries are mainly bought from the downtown areas of the mining cities mostly from Kamsar. The increased mining activities are observed in the grown demand for agricultural products chiefly in the basic agricultural products used for daily consumption, but there are no direct business relations between the companies and farmers.

\section{Conclusion}

Conflict in the Boké mining area represents the main challenge to promote foreign direct investment to economic development and sustainable mining. At the end of our investigation, the aggregate conflict-generating factors are to be understood primarily by the presence of mining companies and the industrial practices they generate, the weakness of social and sovereign benefits of the State, and in the sociological, economic, and history of the region. The disruptions to the living environment resulting from extractive activities are not neutralized, at the current stage, by unsustainable compensatory measures. The ongoing experiments of FODEL and ANAFIC nevertheless appear to be hopeful, but ineffective and insufficient to deal furthermore with the whole problems linked to the compensation process. Greater rigor in the management of these funds would guarantee a better contribution to local development. Mining companies would derive better approaches to managing community relations by considering the depths of sociological, cultural, economic, and historical particularities of the region. A study on the sociohistorical of mining areas will be of great contribution to this end from good management of the FODEL and the ANAFIC actions into the collectivities. The problem of the supply of water and electricity put forward in most of the claims in the large urban centers of Boké could be resolved through an innovative public-private partnership founded on the mining revenues distribution, companies respect to the commitment of local content and CSR in mining localities. As many companies have settled in Boké, it is easier for them to find common solutions with local community members who have had experience with the extractive industries, but also to improve the professional skills of locals on the basic work skills of the mining enterprises. Companies need to strive for dialog and true cooperation with the local community within the elderly people, the civil society members, the organization of young people, and women. Yet, successful communication is not only the responsibility of the companies. The local populations need also to see the possible benefits of working together with the companies so that they can express their opinions through constructive criticism rather than roadblocks and other forms of direct action [7]. All these measures have to be founded on a good governance policy from the State, and companies' fulfillment of the local content and CSR towards the communities. Entrepreneurial knowledge based on local economic development activities is a sure and effective means of development of the region independently of mining companies and sustainable support after mining in the area.

\section{Acknowledgements}

At the end of this complex survey in the Boké region, we express our sincere thanks to all those who accompanied and supported us. Most of these challenges have been overcome through the assistance of many people who have been of remarkable use to us. This is a great opportunity to extend through these lines our sincere thanks to Dr. Daouda Keita in Higher Institute of Mining and Geology of Boke, Abdoulaye Keita Journalist in Boké, Mamadou Safaie Diallo vice mayor of the Boké Urban Commune, Mohamed Mara of the NGO WANEP-Guinea, M. Béavogui the General secretary of Boké mayor-council, the General Secretary of the Ministry of Mines Sadou Nimaga, Ibrahima Sory Soumah Head of community relations department in the Ministry of Mines and Geology, BARRY Ansoumane (SMB), Amadou Laouratou Diallo municipal councilor in Sangaredi, etc. We hope that the following findings in this article will serve to reorient public policies in the direction of building a peaceful cohabitation environment between mining companies and the riparian population.

\section{References}

[1] Anis C. (2018). Does CSR Disclosure Solve Social Conflicts between Companies and Community? An Empirical Evidence. E3S Web Conf; 73. Epub ahead of print. DOI: 10.1051/e3sconf/20187308018.

[2] Adonteng-Kissi O, Adonteng-Kissi B. (2017) Living with conflicts in Ghana's Prestea mining area: Is community engagement the answer? J Sustain Min. 16: 196-206.

[3] Conteh FM, Maconachie R. (2019). Spaces for contestation: The politics of community development agreements in Sierra Leone. Resour Policy, 61: 231-240.

[4] Andrews N, Essah M. (2020). The sustainable development conundrum in gold mining: Exploring 'Open, Prior and Independent Deliberate Discussion' as a community-centered framework. Resour Policy; 68. Epub ahead of print 2020. DOI: 10.1016/j.resourpol. 101798.

[5] Zeng L, Guo J, Wang B, Jun Lv, Wang Q. (2019). Analyzing sustainability of Chinese coal cities using a decision tree modeling approach. Resour Policy; 64: 101501. 
[6] Widder L, D. Pacioni T, Bocoum O. (2020). Sustainably Growing Guinea's Bauxite-Aluminum Industry. Reg Dev Africa. DOI: 10.5772/intechopen.86471.

[7] Tiainen H, Sairinen R, Novikov V. (2014). Mining in the Chatkal Valley in Kyrgyzstan-Challenge of social sustainability. Resour Policy. 39: 80-87.

[8] Cheshire L, Everingham JA, Lawrence G. (2014). Governing the impacts of mining and the impacts of mining governance: Challenges for rural and regional local governments in Australia. J Rural Stud; 36: 330-339.

[9] Ocampo-Melgar A, Gironás J, Valls A. (2018). A rule-based approach for preventive identification of potential conflictive criteria in mining operations in Chile. J Clean Prod; 184: $559-568$.

[10] Campbell B, Hatcher P. (2019). Neoliberal reform, contestation, and relations of power in mining: Observations from Guinea and Mongolia. Extr Ind Soc; 6: 642-653.

[11] Loayza N, Rigolini J. (2016). The Local Impact of Mining on Poverty and Inequality : Evidence from the Commodity Boom in Peru. World Dev. 84: 219-234.

[12] Kivinen S, Kotilainen J, Kumpula T. (2020). Mining conflicts in the European Union: Environmental and political perspectives. Fennia. 198: 163-179.

[13] Ştefănescu L, Alexandrescu F. (2020). Environmental protection or subversion in mining? Planning challenges, perspectives, and actors at the largest gold deposit in Europe. Land use policy. 95: 103649.000000000.

[14] Engels Kristina BD. (2016). Mining conflicts in sub-Saharan Africa : Global Change - Local Conflicts? Conflicts over land in Latin America and sub-Saharan Africa; 14195.

[15] Scheidel A., Del Bene D., Liu J., Navas G., Mingorría S., Demaria F., Avila S., Roy B., Ertör I., Temper L., MartínezAlier.,(2020). Environmental conflicts and defenders: A global overview. Glob Environ Chang. DOI: 10.1016/j.gloenvcha.2020.102104.

[16] Haslam PA. (2021). The micro-politics of corporate responsibility : How companies shape protest in communities affected by mining. World Dev, 139: 105322.

[17] Sauerwein T. (2020). Gold mining and development in Côte d'Ivoire: Trajectories, opportunities and oversights. Land use policy, 91: 104323 .

[18] Andrews T, Elizalde B, Billon P Le, Oh C. H., Reyes D., Tomson I. (2017). The Rise in Conflict Associated with Mining Operations: What Lies Beneath? Can Int Resources Dev Institute; 126.

[19] Worlanyo AS, Jiangfeng L. (2020). Evaluating the environmental and economic impact of mining for post-mined land restoration and land-use: A review. J Environ Manage; 111623

[20] Horsley J, Prout S, Tonts M, Ali S H. (2015). The Extractive Industries and Society Sustainable livelihoods and indicators for regional development in mining economies. Biochem Pharmacol; 2: 368-380.

[21] Jaskoski M. (2014). Environmental Licensing and Conflict in Peru's Mining Sector: A Path-Dependent Analysis. World Dev; 64: 873-883.
[22] Sternberg T. (2020). Conflict and contestation in Kyrgyz mining infrastructure. Extr Ind Soc; 7: 1392-1400.

[23] Diallo P. (2017). Social insecurity, stability and the politics in West Africa: A case study of artisanal and small-scale diamond mining in Guinea, 1958-2008. Extr Ind Soc; 4: 489496.

[24] Matthieu Bolay. (2016) Artisanal Gold Miners Encountering Large-Scale Mining in Guinea: Expulsion, Tolerance and Interference 1. Small- and Large-Scale Gold Mining: Who Competes for What ?; 187-204.

[25] Bolay M. (2014). When miners become 'foreigners': Competing categorizations within gold mining spaces in Guinea. Resour Policy; 41: 117-127.

[26] ITIE. (2018). Initiative pour la Transparence dans les Industries Extractives (ITIE-Guinea). 0-20.

[27] Naraghi S, Stanski V. (2018). Conflict Prevention, Resolution and Reconstruction. Incl Secur Sustain. Peace. A Toolkit Advocacy Action; 1-68.

[28] Arellano-yanguas J. (2018). WORKING PAPER 300 Curse ? The New Natural Resource Policy Agenda and the Mining Revival in Peru.

[29] Willice O. (2018). Mining Conflicts and Corporate Social Responsibility in Kenya's Nascent Mining Industry: A Call for Legislation. http://dx.doi.org/10.5772/intechopen.77373.

[30] O'Brochta W. (2019). A meta-analysis of natural resources and conflict. Res Polit. 6. DOI: 10.1177/2053168018818232.

[31] Zhang Y, Cui M. (2020). Determining the innovation efficiency of resource-based cities using a relational network DEA model: Evidence from China. Extr Ind Soc. 7: 1557-1566.

[32] Arvanitis Y, Weigert M. (2017). Turning resource curse into development dividends in Guinea-Bissau. Resour Policy; 53: 226-237.

[33] Muhammad N, Aviral T, Sana M, Shahbaz M. (2019). Modeling volatility of precious metals markets by using regime-switching GARCH models. 64: 1-8.

[34] United States Institute of Peace/Washington. (2018). A Study Guide Series on Peace and Conflict For Independent Learners and Classroom Instructors Natural, Natural Resources, Conflict, and Conflict Resolution.

[35] Zeng M, Zhan JV. (2015). Sharing resource wealth for peace: A Chinese strategy to cope with the resource curse. Extr Ind Soc. 2: 302-309.

[36] Johnston LA. (2017). Steel pipe dreams: A China-Guinea and China-Africa lens on prospects for Simandou's iron ore. Extr Ind Soc. 4: 278-289.

[37] Ministry. M. G. (2020). Impact of the Mining sector in Guinea Economy. Ministry of Mines and Geology Report.

[38] Sidiki S. (2019). Bauxite Mining in the Boké Region (Western Guinea): Method Used and Impacts on Physical Environment. European Journal of Sustainable Development Research, 3 (3), em0087. https://doi.org/10.29333/ejosdr/5735.

[39] UN. Human Development Report 2020 -The Next Frontier: Human Development and the Anthropocene, Briefing note for Uganda. 1-6. 
[40] Pairault T. (2019). Des nids pour le phénix: L' Afrique et les zones économiques spéciales " chinoises" To cite this version: HAL. Id: halshs-02047370. https://halshs.archivesouvertes.fr/halshs-02047370.

[41] Chuhan-pole P, Dabalen AL. (2018). Mining in Afrique. World Bank. 1-89.

[42] Chuhan-Pole P, Dabalen AL, Land BC. (2019). L'exploitation minière en Afrique: Les communautés locales en tirent-elles parti?. Groupe Banque Mondiale et Agence Francaise de Developpement. DOI: 10.1596/978-1-4648-1395-5.

[43] Rey P, Mazalto M, Jeanne I. (2021). Reconciling standards and the operational needs of mining projects in Africa: Examples from Guinea. Extr Ind Soc. 8: 23-31.

[44] Bah M A. (2019). Rapport provisoire d'étude de référence du SARP-PACV, ANAFIC (Guinea). 1-54

[45] Akabzaa T, Darimani A. (2001). Impact of mining sector investment in Ghana: A study of the Tarkwa mining region. A draft report prepared for SAPRI. Third World Netw. 1-70.

[46] Mensah AK, Mahiri IO, Owusu O, Mireku OD., Wireko I., Kissi EA. (2018). Environmental Impacts of Mining: A Study of Mining Communities in Ghana. 3: 81-94.

[47] Jo BW, Khan RMA. (2017). An event reporting and earlywarning safety system based on the internet of things for underground coal mines: A case study. Appl Sci; 7. DOI: 10.3390/app7090925.

[48] Kemp D, Owen JR. (2013). Community relations and mining: Core to business but not "core business". Resour Policy, 38: 523-531.

[49] Avci D, Adaman F, Özkaynak B. (2010). Valuation languages in environmental conflicts: How stakeholders oppose or support gold mining at Mount Ida, Turkey. Ecol Econ. 70: $228-238$.

[50] Sánchez-Vázquez L, Espinosa MG, Eguiguren MB. (2016). Perception of socio-environmental conflicts in mining areas: The case of the mirador project in Ecuador. Ambient e Soc. 19: 23-44.

[51] Andrews N. (2018). Land versus livelihoods: Community perspectives on dispossession and marginalization in Ghana's mining sector. Resour Policy, 58: 240-249.

[52] Sukri, Ariana, Naharuddin A, Ekawaty D. (2020). Conflict as a negotiation strategy of society around mining activities. IOP Conf Ser Earth Environ Sci; 575. DOI: 10.1088/17551315/575/1/012205.

[53] KPMG International Cooperative. Guinea Country mining guide. (2014).

https://www.google.com/search? sxsrf $=A C Y B G N Q m p N h P w n p$
8kOCzatdwJ7hULVVg4Q\%3A1572311471847\&source=hp\&e $i=r 5$ G3XdSvMZLrwQOapr6IDA\& $q=$ mining + sector + in + guin $e a+$ conakry\&oq=Mining\&gs $l=p s y-a$ 2014; 30 .

[54] Breaking News: Responsible mining. a toolkit for the prevention and mediation of conflicts in the development of the mining sector.pdf.

[55] Icmm. (2002). Research on company-community conflict, www.icmm.com/document/216.

[56] Adonteng-Kissi O. (2015). Identifying the Sources, Causes, and Costs Of Conflicts in the Prestea Mining Community. Int J Community Dev. 3: 64-78.

[57] Que S, Awuah-offei K, Samaranayake VA. (2015). Classifying critical factors that influence community acceptance of mining projects for discrete choice experiments in the United States. J Clean Prod. 87: 489-500.

[58] Cesar S, Jhony O. (2021). Making or breaking social license to operate in the mining industry: Factors of the main drivers of social conflict. J Clean Prod. 278: 123640.

[59] Breaking new ground: mining, minerals, and sustainable development. Resources Policy 29 (2003) 69-74. Earthscan Publications Ltd., London, 2002, 441 pages, ISBN 1-85383942-6, (softcover).

[60] DB Subedi (2017). Early Warning and Response for Preventing Radicalization and Violent Extremism, Peace Review, 29: $2, \quad 135-143, \quad$ DOI: 10.1080/10402659.2017.1308185.

[61] Maconachie R, Binns T. Beyond the resource curse? Diamond mining, development, and post-conflict reconstruction in Sierra Leone. Resour Policy. 32: 104-115.

[62] Breaking New Ground (2002). Local Communities and Mines. IIED. 198-219. https://pubs.iied.org/sites/default/files/pdfs/migrate/G00901.

[63] Opoku Mensah S, Asare Okyere S. (2014). Mining, environment and community conflicts: a study of companycommunity conflicts over gold mining in the Obuasi Municipality of Ghana. J Sustain Dev Stud. 5: 64-99.

[64] Novoselov A, Potravny I, Novoselova I, Gassiy V. (2020). Compensation fund as a tool for sustainable development of the Arctic indigenous communities. Polar Sci. 100609.

[65] Yang X, Ho P. (2020). The Extractive Industries and Society Mining institutions, contention and credibility : Applying the Conflict Analysis Model to court cases in China. Extr Ind Soc. 7: 1011-1021.

[66] Corrigan CC. (2018). Corporate social responsibility and local context: The case of mining in Southern Africa. Resour Policy, 55: 233-243. 